\title{
Effectiveness of Reablement: A Systematic Review
}

\section{Efficacité de l'autonomisation : une revue systématique}

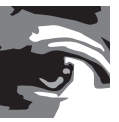

\author{
ANNIE TESSIER, PHD \\ Researcher, Institut national d'excellence en santé et en services sociaux \\ Montréal, QC \\ MARIE-DOMINIQUE BEAULIEU, MD, MSC, FCFP \\ Full professor, Department of Family and Emergency Medicine \\ University of Montréal \\ Montréal, QC \\ CARRIE ANNA MCGINN, MSC \\ Researcher, Institut national d'excellence en santé et en services sociaux \\ Montréal, QC \\ RENÉE LATULIPPE, MA \\ Researcher, Institut national d'excellence en santé et en services sociaux \\ Montréal, QC
}

\begin{abstract}
The ageing of the population and the increasing need for long-term care services are global issues.

Some countries have adapted homecare programs by introducing an intervention called reablement, which is aimed at optimizing independence. The effectiveness of reablement, as well as its different service models, was examined. A systematic literature review was conducted using MEDLINE, CINAHL, PsycINFO and EBM Reviews to search from 2001 to 2014. Core characteristics and facilitators of reablement implementation were identified from international experiences.

Ten studies comprising a total of 14,742 participants (including four randomized trials, most of excellent or good quality) showed a positive impact of reablement, especially on health-related quality of life and service utilization. The implementation of reablement was studied in three regions, and all observed a reduction in healthcare service utilization. Considering its effectiveness and positive impact observed in several countries, the implementation of reablement is a promising avenue to be pursued by policy makers.
\end{abstract}




\section{Résumé}

Le vieillissement de la population et l'augmentation des besoins en services de longue durée sont des préoccupations mondiales. Certains pays ont adapté leurs programmes de soutien à domicile en y intégrant une intervention nommée « autonomisation », laquelle vise à optimiser l'indépendance des clients. Nous avons examiné l'efficacité de l'autonomisation ainsi que ses divers modèles de services. Nous avons procédé à une revue systématique à l'aide des bases de données MEDLINE, CINAHL et PsycINFO ainsi que des revues fondées sur les données probantes, entre 2001 et 2014. Un examen d'expériences internationales a permis de déterminer les caractéristiques clés de l'autonomisation et les facteurs favorisant le succès de son implantation.

Dix études qui représentent un échantillon de 14742 participants (dont quatre essais cliniques aléatoires, pour la plupart de bonne à excellente qualité) montrent un effet positif de l'autonomisation, particulièrement sur le plan de la qualité de vie liée à la santé et sur le plan de l'utilisation des services. Nous avons étudié l'implantation de l'autonomisation dans trois régions, lesquelles ont toutes connu une réduction de l'utilisation des services de soins de santé. En raison de son efficacité et de l'impact positif observé dans plusieurs pays, l'implantation de l'autonomisation est une avenue prometteuse que devraient considérer les responsables de politiques.

\section{Introduction}

The ageing population and the increasing need for long-term care services are global concerns. Some countries have adapted their homecare programs by introducing restorative homecare, or reablement, to optimize the independence of community-dwelling adults. Reablement is defined as services for seniors with physical or mental disabilities that help them adapt to their condition by learning or re-learning the skills needed to function in everyday life (Social Care Institute for Excellence 2013). The objective is to help seniors live independent and fulfilling lives, while appropriately reducing the need for continuing support and reducing the cost of long-term services. Key characteristics are the provision of shortterm, goal-oriented interventions developed by an interdisciplinary team with the user, and delivery of the interventions by a non-professional under the supervision of a professional (Table 1). The focus is on promoting and optimizing functional independence rather than resolving health problems.

The objective of this paper is to examine the effectiveness of reablement, and to identify factors that might contribute to successful implementation for Canadian policy makers. A report in French intended for Quebec policy makers regarding implementation of reablement can be consulted for more details (Tessier et al. 2015). 
TABLE 1. Core characteristics of reablement

\begin{tabular}{|l|l|}
\hline \multirow{3}{*}{ Structure } & Interdisciplinary team of varying composition \\
\cline { 2 - 3 } & Training and ongoing support for team members \\
\hline \multirow{3}{*}{ Process } & Free services for 6-12 weeks \\
\cline { 2 - 3 } & Programs accessible to everybody, but some prioritize those leaving the hospital \\
\cline { 2 - 3 } & Generic interventions (not requiring a high degree of professional specialization) offered by non-professionals \\
\cline { 2 - 3 } & Evaluation of users by professionals via structured and comprehensive assessment \\
\cline { 2 - 3 } & Goal-oriented plan developed with users and their caregivers \\
\cline { 2 - 3 } & Treatment plan reviewed regularly \\
\cline { 2 - 3 } & Weekly team meeting \\
\hline \multirow{2}{*}{ Outcome } & Improved ADL, IADL and HRQoL and less service utilization \\
\hline
\end{tabular}

$\mathrm{ADL}=$ activity of daily living; $\mathrm{ADL}=$ instrumental activity of daily living; $\mathrm{HRQOL}=$ health-related quality of life.

\section{Methods}

\section{Effectiveness of reablement}

A systematic review was conducted to evaluate the effectiveness of reablement. For a study to be considered, the participants had to be over 65 years old, have functional limitations and be living at home. The intervention did not need to be called reablement or restorative care, but had to promote functional independence, be of short duration (6-12 weeks) and be provided by paid workers as part of homecare services. The intervention had to be multidisciplinary in nature. The outcomes of interest were functional status in activities of daily living (ADL) and instrumental activities of daily living (IADL), health-related quality of life (HRQoL) and healthcare service utilization. Systematic reviews, meta-analyses, randomized controlled trials (RCTs) and quasi-experimental and qualitative studies were eligible for inclusion. Case reports were excluded: studies had to have a control group in order to address whether the change in outcome was due to the natural evolution of the person's condition or to the intervention.

Literature searching was carried out in MEDLINE (PubMed), CINAHL (EBSCO), PsycINFO (OvidSP) and EBM Reviews (OvidSP); the latter included the Cochrane Central Register of Controlled Trials and the Cochrane Database of Systematic Reviews. Several search terms were used, including homecare, reablement, autonomy, seniors and aged. Articles had to be published in either English or French between January 2001 and August 2014. The search strategy is available in Appendix 1 (available at: http://www.longwoods.com/content/24594).

Articles were selected independently by two researchers (AT and MDB). Any discrepancies were resolved by consensus. Articles were excluded if they did not pertain to people older than 65 years old receiving an intervention promoting autonomy, or if they did not include the outcomes of interest (function, HRQoL or service utilization). The studies selected from the 
literature had to have control groups in order to be able to determine whether the change in outcome was due to the natural evolution of the person's condition or to the intervention. One researcher (AT) extracted information from all articles using a template that included research design, client characteristics, nature of the intervention (e.g., goals, duration and composition of the team), environment (e.g., country, urban or rural setting and multi-ethnic context), comparator, outcomes and adverse events. A second researcher validated the accuracy of the data extraction for $20 \%$ of the articles. Methodological quality of each study was assessed independently by two researchers (AT and MDB) with the Critical Appraisal Skills Programme (CASP) (Critical Appraisal Skills Programme 2014) tool for RCTs, and with the Assessment of Multiple Systematic Reviews (AMSTAR) (Shea et al. 2009) tool for systematic reviews.

\section{Factors contributing to success}

Australia, New Zealand and the UK have been at the forefront of developing and testing reablement. Furthermore, their healthcare systems are similar to Canada's. A narrative review of the non-peer-reviewed literature was conducted to examine the service models used in these regions, as well as the facilitators of and barriers to implementation according to this international experience. The Google Scholar search engine was queried to retrieve information. In addition, several websites of reputable societies were explored, including the Guidelines International Network (GIN), the Centre for Reviews and Dissemination (CRD), the International Network of Agencies for Health Technology Assessment (INAHTA), the Social Care Institute for Excellence (SCIE) and the National Institute for Health and Care Excellence (NICE) (Appendix 1).

\section{Results}

\section{Effectiveness of reablement}

The literature search yielded 621 articles: 43 were identified based on the title and abstract. The full articles were read, resulting in further exclusion. The remaining 13 articles originated from 10 individual studies (Burton et al. 2013a, 2013b; Glendinning et al. 2011; King et al. 2012a, 2012b; Lewin et al. 2013a, 2013b; 2014; Lewin and Vandermeulen 2010; Parsons et al. 2012, 2013; Senior et al. 2014; Tinetti et al. 2002). Seven out of 10 were considered to be of either excellent or good quality, while three were of fair quality. There were four RCTs, four controlled before-and-after studies, one data linkage and one qualitative study, collectively including close to 15,000 participants. All of the included studies referred to the intervention either as reablement or restorative care. Study characteristics, quality and results are reported in Table 2 . On average, the service users in the studies were 78-80 years old and required minimal to moderate help with their ADLs.

Seven studies examined the effect of reablement on various aspects of functional capacity (Table 2). Three studies reported no effects of reablement (Burton et al. 2013b; King et al. 2012b; Senior et al. 2014). Two studies looking exclusively at ADLs demonstrated an 
improvement in both groups of participants (reablement or usual homecare services) (Lewin et al. 2013a; Tinetti et al. 2002). In three studies, either ADL, IADL or mobility showed greater improvement with reablement than with usual services (Lewin and Vandermeulen 2010; Parsons et al. 2013; Tinetti et al. 2002). Finally, reablement was associated with greater improvement in HRQoL compared to usual homecare services in four studies (total sample of 1,706 participants). This difference was statistically significant in three studies (Glendinning et al. 2011; King et al. 2012b; Parsons et al. 2012), and not significant in one (Lewin et al. 2013a).

TABLE 2. Characteristics of included studies

\begin{tabular}{|c|c|c|c|c|c|}
\hline \multirow{2}{*}{$\begin{array}{l}\text { Study (first author, } \\
\text { year; design; } \\
\text { sample size; } \\
\text { country/region) }\end{array}$} & \multirow[b]{2}{*}{ Quality } & \multicolumn{4}{|c|}{ Results (for the intervention group, compared with controls) } \\
\hline & & $\begin{array}{l}\text { Functional } \\
\text { capacity }\end{array}$ & HRQoL & Service utilization & Other results \\
\hline $\begin{array}{l}\text { Burton 20।3a, 20।3b; } \\
\text { CBA; } n=506 ; \\
\text { Australia }\end{array}$ & Fair & $\begin{array}{l}\text { No effect on physical } \\
\text { activity level (MT, LT) }\end{array}$ & & & \\
\hline $\begin{array}{l}\text { Glendinning 2011; } \\
\mathrm{CBA} ; n=1,015 ; \mathrm{UK}\end{array}$ & Fair & & $\begin{array}{l}\text { Greater } \\
\text { improvement } \\
\text { (clinically significant } \\
\text { and SS) (ST) }\end{array}$ & $\begin{array}{l}60 \% \text { reduction in } \\
\text { ongoing homecare } \\
\text { needs }\end{array}$ & $\begin{array}{l}\text { NS differences } \\
\text { in average costs } \\
\text { between the two } \\
\text { groups (ST) (initial } \\
\text { cost of reablement } \\
\text { offset by a } 60 \% \\
\text { decrease in long- } \\
\text { term costs) }\end{array}$ \\
\hline $\begin{array}{l}\text { King 20 I 2a; } \\
\text { Qualitative; } n=25 \text {; } \\
\text { New Zealand }\end{array}$ & Fair & & & & $\begin{array}{l}\text { Greater paid- } \\
\text { worker job } \\
\text { satisfaction; reduced } \\
\text { staff turnover }\end{array}$ \\
\hline $\begin{array}{l}\text { King } 20 \mathrm{I} 2 \mathrm{~b} ; \mathrm{RCT} ; \\
n=186 ; \mathrm{New} \\
\text { Zealand }\end{array}$ & High & $\begin{array}{l}\text { NS improvement in } \\
\text { both groups (ST) }\end{array}$ & $\begin{array}{l}\text { Greater } \\
\text { improvement (SS, } \\
\text { but not clinically } \\
\text { significant) (ST) }\end{array}$ & $\begin{array}{l}\text { Greater proportion } \\
\text { of users needing } \\
\text { fewer services (SS) } \\
\text { (ST) }\end{array}$ & \\
\hline $\begin{array}{l}\text { Lewin 20I0; CBA; } \\
n=200 ; \text { Australia }\end{array}$ & Moderate & $\begin{array}{l}\text { Only the intervention } \\
\text { group showed } \\
\text { improvement in } \\
\text { ADL, IADL and } \\
\text { mobility (SS) (ST) }\end{array}$ & & $\begin{array}{l}\text { Lower probability of } \\
\text { continuing to require } \\
\text { services (SS) (ST) }\end{array}$ & $\begin{array}{l}\text { NS improvement on } \\
\text { mood in both groups } \\
\text { (ST) }\end{array}$ \\
\hline $\begin{array}{l}\text { Lewin 20।3b; Data } \\
\text { linkage; } n=10,368 \\
\text { Australia }\end{array}$ & High & & & $\begin{array}{l}\text { Lower probability of } \\
\text { continuing to require } \\
\text { services (SS) (LT) }\end{array}$ & $\begin{array}{l}\text { Cumulative costs } \\
\text { substantially lower } \\
\text { in the intervention } \\
\text { group (MT and TL); } \\
\text { savings of } \$ 7,345 \\
\text { CAD per person } \\
\text { after } 3 \text { years; median } \\
\text { cost of first } 3 \text { months } \\
\text { of intervention about } \\
\text { half that of current } \\
\text { services and less than } \\
\text { a third after } 5 \text { years } \\
\text { (ST and LT) }\end{array}$ \\
\hline
\end{tabular}


TABLE 2. Characteristics of included studies (continued)

\begin{tabular}{|c|c|c|c|c|c|}
\hline \multirow{2}{*}{$\begin{array}{l}\text { Study (first author, } \\
\text { year; design; } \\
\text { sample size; } \\
\text { country/region) }\end{array}$} & \multirow[b]{2}{*}{ Quality } & \multicolumn{4}{|c|}{ Results (for the intervention group, compared with controls) } \\
\hline & & $\begin{array}{l}\text { Functional } \\
\text { capacity }\end{array}$ & HRQ०L & Service utilization & Other results \\
\hline $\begin{array}{l}\text { Lewin 20 I3a; } \\
\text { Lewin 20 I4; RCT; } \\
n=750 ;(n=300 \\
\text { for data on function } \\
\text { and HRQoL); } \\
\text { Australia }\end{array}$ & Moderate & $\begin{array}{l}\text { NS difference } \\
\text { between the groups: } \\
\text { both improved (ST) }\end{array}$ & $\begin{array}{l}\text { NS difference } \\
\text { between the groups: } \\
\text { both improved (ST) }\end{array}$ & $\begin{array}{l}\text { NS difference } \\
\text { between groups } \\
\text { for hours of } \\
\text { homecare services, } \\
\text { hospital admissions, } \\
\text { emergency } \\
\text { department visits } \\
\text { (ST and MT) in the } \\
\text { intention to treat } \\
\text { analysis, SS difference } \\
\text { in the analysis per } \\
\text { the actual treatment } \\
\text { received }\end{array}$ & $\begin{array}{l}\text { Average total home } \\
\text { services costs } 22 \% \\
\text { lower at I year and } \\
30 \% \text { lower at } 2 \\
\text { years (NS) }\end{array}$ \\
\hline $\begin{array}{l}\text { Parsons 20I2; } \\
\text { Parsons 20 I3; RCT; } \\
n=205 ; \mathrm{New} \\
\text { Zealand }\end{array}$ & High & $\begin{array}{l}\text { Greater } \\
\text { improvement (SS) } \\
\text { (ST) }\end{array}$ & $\begin{array}{l}\text { Only the intervention } \\
\text { group showed } \\
\text { improvement (SS) } \\
\text { (ST) }\end{array}$ & & $\begin{array}{l}\text { NS difference } \\
\text { between the groups } \\
\text { for social support } \\
\text { (ST) }\end{array}$ \\
\hline $\begin{array}{l}\text { Senior 20 I4; RCT; } \\
n=105 ; \text { New } \\
\text { Zealand }\end{array}$ & Moderate & $\begin{array}{l}\text { NS difference } \\
\text { between the groups } \\
\text { for } A D L, I A D L(M T)\end{array}$ & & $\begin{array}{l}\text { NS reduction in the } \\
\text { risk of death and/ } \\
\text { or residential care } \\
\text { placement (MT) }\end{array}$ & $\begin{array}{l}\text { SS slower rate of } \\
\text { decline in physical } \\
\text { health of caregivers } \\
\text { (MT); no effect on } \\
\text { caregiver burden } \\
\text { (MT) }\end{array}$ \\
\hline $\begin{array}{l}\text { Tinetti 2002; CBA; } \\
n=1,382 ; \text { US }\end{array}$ & Moderate & $\begin{array}{l}\text { Greater } \\
\text { improvement in } \\
\text { IADL and mobility } \\
\text { (SS) (ST); NS } \\
\text { difference between } \\
\text { groups for ADL: } \\
\text { both improved }\end{array}$ & & $\begin{array}{l}\text { SS reduction in the } \\
\text { risk of residential } \\
\text { care placement, } \\
\text { emergency } \\
\text { department visits and } \\
\text { length of homecare } \\
\text { episode (ST) }\end{array}$ & \\
\hline
\end{tabular}

$\mathrm{ADL}=$ activity of daily living; $\mathrm{CBA}=$ controlled before-and-after study; $\mathrm{HRQ} \mathrm{L}=$ health-related quality of life; IADL = instrumental activity of daily living; $\mathrm{LT}=$ long term (more than 3 years); MT = medium term ( $1-3$ years); NS = not statistically significant; RCT = randomized controlled trial; SS = statistically significant; $\mathrm{ST}=$ short term (less than I year).

According to seven studies (eight articles; total sample of 14,006 participants), reablement had a positive effect on service utilization in the first year. Fewer people required homecare services after receiving reablement compared to those receiving usual homecare services (Glendinning et al. 2011; King et al. 2012b; Lewin et al. 2013a, 2013b; 2014; Lewin and Vandermeulen 2010; Senior et al. 2014; Tinetti et al. 2002). The absolute risk reduction ranged across the studies between 55\% at three months and $22 \%$ at 12 months. However, only one study indicated that the effects were maintained in the long term (five years) (Lewin et al. 2013b). Evidence was limited but suggested benefits of reablement on visits to the emergency department, risk of residential care placement and mortality (Lewin et al. 2014; Senior et al. 2014; Tinetti et al. 2002). One study found no effect on caregivers' burden (Senior et al. 2014), while another reported greater job satisfaction in the group of employees providing reablement when compared to those delivering usual homecare services (King et al. 2012a). 
The efficiency of reablement was examined in three studies (total sample of 12,133 participants). Generally, the cost of reablement was higher than that of usual homecare services because reablement requires more resources, including a need for more training, supervision and user evaluation at the outset. In the subsequent months, however, reablement was associated with a decrease in homecare service utilization. In one study, balanced total costs, when both reablement and ongoing homecare services were considered, were achieved within the first year (Glendinning et al. 2011). The results of an RCT suggest that reablement was cost-effective in the long term: the cost of reablement compared with usual homecare was, on average, $22 \%$ lower in the first year, and 30\% lower over two years (Lewin et al. 2014). According to a large database analysis, the median cumulative cost of all homecare services in the reablement group was approximately half that of the usual homecare group at three months, and less than one-third the cost for the 6,656 persons who were followed for nearly five years (Lewin et al. 2013b).

One of the difficulties in establishing the cost-benefit of reablement is the wide differences in cost across clinical settings. For example, the study of Glendinning and colleagues was carried out in five similar clinical settings and reported an average cost per user ranging from $£ 1,609$ to $£ 3,575$ (Glendinning et al. 2011).

\section{Factors contributing to success}

In Australia, New Zealand and the UK, reablement was first introduced in the setting of pilot projects near the beginning of 2000. Such projects showed a reduction in services needed and enhanced user satisfaction (Ghatorae 2013; McLeod and Mair 2009). Consequently, the projects were expanded to service the general population. Most of these regions have gradually moved from insourcing to outsourcing services to non-governmental organizations. The service model is similar from one country to another. In almost all settings, reablement is available to all who need homecare services without discrimination, including those with cognitive impairment, for whom the evidence actually suggests less benefit. Most of the associated services arise from the community rather than from the hospital setting.

Facilitators of and barriers to the success of reablement have been identified through interviews with service managers, users and frontline staff (McLeod and Mair 2009; Rabiee and Glendinning 2011). Similarly, the Social Care Institute for Excellence (SCIE) in the UK has identified contributing factors in their practical guide entitled "Maximising the potential of reablement to support the implementation and delivery of reablement"; these factors are summarized in Table 3 (Social Care Institute for Excellence 2013). Staff training has been recognized as a key element for success, along with the engagement of patients and their caregivers in the reablement plan to establish realistic expectations. An efficient handover process is required, and the scope of services should address social needs. The Care Services Efficiency Delivery (CSED) program, also in the UK, has developed a toolkit, which provides practical help for the implementation of reablement (Care Services Efficiency Delivery 2011). 
TABLE 3. Factors contributing to the success of reablement

\begin{tabular}{|c|c|}
\hline \multirow[t]{2}{*}{ Organization } & Strong and shared vision of the service \\
\hline & Thorough and consistent recording system \\
\hline \multirow[t]{2}{*}{ Service users } & $\begin{array}{l}\text { User characteristics: greatest benefit for those recovering from falls or fractures; benefit may be less for those likely to } \\
\text { need ongoing support such as people with dementia or mental health problems }\end{array}$ \\
\hline & Expectations of service users and carers (reablement worked better for newly referred people) \\
\hline \multirow[t]{3}{*}{ Staff } & Staff commitment, attitude and skills \\
\hline & Training on the principles of delivering a reablement service (e.g., learning to "stand back") \\
\hline & Professionals not necessarily full-time members of the team but frontline workers need access to specialist skills \\
\hline \multirow[t]{4}{*}{ Intervention } & Although regaining physical ability is central, addressing psychological support as well as social needs is also vitally important \\
\hline & Access to equipment \\
\hline & Flexible and prompt intervention \\
\hline & Goal-oriented intervention: goals are established with the user and informal carers, broken down into achievable targets \\
\hline $\begin{array}{l}\text { Program } \\
\text { evaluation }\end{array}$ & $\begin{array}{l}\text { Less focus on time and tasks; instead, reablement should be evaluated on the basis of the outcomes that the service will } \\
\text { support the individual to achieve }\end{array}$ \\
\hline
\end{tabular}

\section{Discussion}

There is good evidence supporting the effectiveness of reablement, particularly regarding HRQoL and service utilization. The added value of recognizing the importance of patient participation in decision-making is well documented, and is likely related to the observed improvement in HRQoL (Legare et al. 2014). Similarly, involving the patient in goal-setting has been shown to lead to significant improvement in HRQoL, possibly via individualized activities (Parsons 2012).

Reablement has shown a positive effect on functional capacity, an effect which is comparable with that of usual homecare services. In the reviewed studies, most users required minimal-to-moderate assistance with their ADL prior to the intervention, and their functional status was assessed with tools that included few complex activities (the Barthel Index and the Nottingham Extended Activity of Daily Living). The small changes reported in functional capacity, which may be surprising considering the reported impact on HRQoL, are possibly due to the limited sensitivity of the assessment tools used. Reablement may be more effective for certain clientele. The homogeneity of the populations studied to date precludes an analysis of who would best benefit from reablement. Specific eligibility criteria may emerge from future studies. Although reablement has the potential to be cost-effective, this is difficult to quantify considering the wide range of costs reported in the literature across settings.

The present results are consistent with two recent systematic reviews. The first was restricted to examining dependency and concluded there was limited evidence for a reduction associated with reablement (Whitehead et al. 2015). The second reported, as in the present study, that reablement had a positive impact on HRQoL, costs and service utilization (Ryburn et al. 2009). 
Three regions have implemented reablement for more than 10 years. They have performed extensive program evaluation, documenting positive impact on service utilization and user satisfaction. Their experience has permitted the identification of factors contributing to success, which policy makers can consider when developing strategic plans to improve homecare. For example, appropriate training has been identified as a facilitator, consistent with Ontario's recent decision to increase support for homecare workers. Finally, reablement can be successfully delivered by non-professionals among whom it has been associated with greater job satisfaction. This offers additional advantages given that recruitment and retention of qualified employees are major challenges in the homecare industry.

In general, seniors wish to live at home. However, in Quebec, as well as in the rest of Canada, almost one in four disabled seniors report unmet homecare needs, one of these being walking outside (Dubuc et al. 2011; Turcotte 2014). One of the challenges of our society is to reduce the barriers to social participation of older people. With this in mind, reablement, which targets both psychosocial and physical needs, is a promising approach.

\section{Conclusion}

One of the objectives of the Quebec Health Ministry's action plan for 2015-2020 is to improve homecare services through systematic evaluation of needs and treatment plans for all elderly (Ministère de la Santé et des Services Sociaux 2015). The reablement approach is in keeping with this objective, with a focus on independence in the community rather than services in institutions. It promotes investment in staff and greater participation of users and their families in decision-making about their care. In addition to improving HRQoL and reducing healthcare service utilization in the short term, reablement can potentially increase employee satisfaction at a reasonable marginal cost.

Correspondence may be directed to: Annie Tessier, Institut national d'excellence en santé et en services sociaux, 2021 Union, Montréal, QC H3A 2S9; e-mail: annie.tessier@inesss.qc.ca.

\section{References}

Burton, E., G. Lewin and D. Boldy. 2013a. "Barriers and Motivators to being Physically Active for Older Home Care Clients". Physical \& Occupational Therapy in Geriatrics 31(1): 21-36. doi:10.3109/02703181.2012.751474.

Burton, E., G. Lewin and D. Boldy. 2013b. "Physical Activity Levels of Older Adults Receiving a Home Care Service". Journal of Aging and Physical Activity 21(2): 140-54.

Care Services Efficiency Delivery. 2011. Home Care Re-Ablement. UK: Department of Health. Retrieved March 30, 2015. <http://webarchive.nationalarchives.gov.uk/20120907090129/http:/www.csed.dh.gov.uk/ homeCareReablement/Toolkit/>.

Critical Appraisal Skills Programme (CASP). 2014. CASP Checklists. Oxford: CASP. Retrieved March 23, 2015. <http://media.wix.com/ugd/dded87_40b9ffobf53840478331915a8ed8b2fb.pdf>.

Dubuc, N., M.F. Dubois, M. Raiche, N.R. Gueye and R. Hebert. 2011. "Meeting the Home-Care Needs of Disabled Older Persons Living in the Community: Does Integrated Services Delivery Make a Difference?" BMC Geriatrics 11: 67. doi:10.1186/1471-2318-11-67.

Ghatorae, H. 2013. Reablement in Glasgow: Quantitative and Qualitative Research. Glasgow, UK: Glasgow City Council. 


\section{Annie Tessier et al.}

Glendinning, C., K. Jones, K. Baxter, P. Rabiee, L.A. Curtis, A. Wilde et al. 2011. Home Care Re-Ablement Services: Investigating the Longer Term Impacts (Prospective Longitudinal Study). York: Social Policy Research Unit, University of York. Retrieved January 20, 2014. <http://socialwelfare.bl.uk/subject-areas/ services-activity/social-work-care-services/spru/135160Reablement10.pdf>.

King, A.I., M. Parsons and E. Robinson. 2012a. "A Restorative Home Care Intervention in New Zealand: Perceptions of Paid Caregivers". Health E Social Care in the Community 20(1): 70-79. doi:10.1111/j.1365-2524.2011.01020.x.

King, A.I., M. Parsons, E. Robinson and D. Jorgensen. 2012b. "Assessing the Impact of a Restorative Home Care Service in New Zealand: A Cluster Randomised Controlled Trial". Health E Social Care in the Community 20(4): 365-74. doi:10.1111/j.1365-2524.2011.01039.x.

Legare, F., D. Stacey, S. Turcotte, M.J. Cossi, J. Kryworuchko, I.D. Graham et al. 2014. “Interventions for Improving the Adoption of Shared Decision Making by Healthcare Professionals". Cochrane Database of Systematic Reviews 12(5): CD006732. doi:10.1002/14651858.CD006732.pub3.

Lewin, G. and S. Vandermeulen. 2010. "A Non-Randomised Controlled Trial of the Home Independence Program (HIP): An Australian Restorative Programme for Older Home-Care Clients". Health \& Social Care in the Community 18(1): 91-99. doi:10.1111/j.1365-2524.2009.00878.x.

Lewin, G., K. De San Miguel, M. Knuiman, J. Alan, D. Boldy, D. Hendrie et al. 2013a. “A Randomised Controlled Trial of the Home Independence Program, an Australian Restorative Home-Care Programme for Older Adults". Health \& Social Care in the Community 21(1): 69-78. doi:10.1111/j.1365-2524.2012.01088.x.

Lewin, G.F., H.S. Alfonso and J.J. Alan. 2013b. “Evidence for the Long Term Cost Effectiveness of Home Care Reablement Programs". Clinical Interventions in Aging 8: 1273-81. doi:10.2147/cia.s49164.

Lewin, G., J. Allan, C. Patterson, M. Knuiman, D. Boldy and D. Hendrie. 2014. "A Comparison of the HomeCare and Healthcare Service Use and Costs of Older Australians Randomised to Receive a Restorative or a Conventional Home-Care Service". Health E Social Care in the Community 22(3): 328-36. doi:10.1111/ hsc.12092.

McLeod, B. and M. Mair. 2009. Evaluation of City of Edinburgh Council Home Care Re-Ablement Service. Edinburgh, UK: Scottish Government Social Research.

Ministère de la Santé et des Services Sociaux. 2015. Plan stratégique 2015-2020. Québec, QC. Publication №: 15-717-02W.

Parsons, J., P. Rouse, E.M. Robinson, N. Sheridan and M.J. Connolly. 2012. "Goal Setting as a Feature of Homecare Services for Older People: Does it Make a Difference?” Age Ageing 41(1): 24-29. doi:10.1093/ageing/ afr118.

Parsons, J.G., N. Sheridan, P. Rouse, E. Robinson and M. Connolly. 2013. "A Randomized Controlled Trial to Determine the Effect of a Model of Restorative Home Care on Physical Function and Social Support among Older People." Archives of Physical Medicine and Rebabilitation 94(6): 1015-22. doi:10.1016/j.apmr.2013.02.003.

Rabiee, P. and C. Glendinning. 2011. "Organisation and Delivery of Home Care Re-Ablement: What Makes a Difference?" Health E Social Care in the Community 19(5): 495-503. doi:10.1111/j.1365-2524.2011.01010.x.

Ryburn, B., Y. Wells and P. Foreman. 2009. “Enabling Independence: Restorative Approaches to

Home Care Provision for Frail Older Adults." Health E Social Care in the Community 17(3): 225-34. doi:10.1111/j.1365-2524.2008.00809.x.

Senior, H.E., M. Parsons, N. Kerse, M.H. Chen, S. Jacobs, S.V. Hoorn et al. 2014. "Promoting Independence in Frail Older People: A Randomised Controlled Trial of a Restorative Care Service in New Zealand." Age Ageing 43(3): 418-24. doi:10.1093/ageing/afu025.

Shea, B.J., C. Hamel, G.A. Wells, L.M. Bouter, E. Kristjansson, J. Grimshaw et al. 2009. "AMSTAR Is a Reliable and Valid Measurement Tool to Assess the Methodological Quality of Systematic Reviews." Journal of Clinical Epidemiology 62(10): 1013-20. doi:10.1016/j.jclinepi.2008.10.009.

Social Care Institute for Excellence (SCIE). 2013. SCIE guide 49: Maximising the Potential of Reablement. London: SCIE.

Tessier, A., M.D. Beaulieu, R. Latulippe and C.A. McGinn. 2015. L'autonomisation des personnes en perte d'autonomie liée au vieillissement. Québec: Institut national d'excellence en santé et en services sociaux (INESSS). 
Tinetti, M.E., D. Baker, W.T. Gallo, A. Nanda, P. Charpentier and J. O’Leary. 2002. “Evaluation of Restorative Care vs Usual Care for Older Adults Receiving an Acute Episode of Home Care." JAMA 287(16): 2098-105.

Turcotte, M. 2014. Canadians with Unmet Home Care Needs. Insights on Canadian Society. Ottawa, ON: Statistics Canada. Catalogue № 75006 X.

Whitehead, P.J., E.J. Worthington, R.H. Parry, M.F. Walker and A.E. Drummond. 2015. "Interventions to Reduce Dependency in Personal Activities of Daily Living in Community Dwelling Adults Who Use Homecare Services: A Systematic Review." Clinical Rehabilitation 29(11):1064-76. doi:10.1177/0269215514564894.

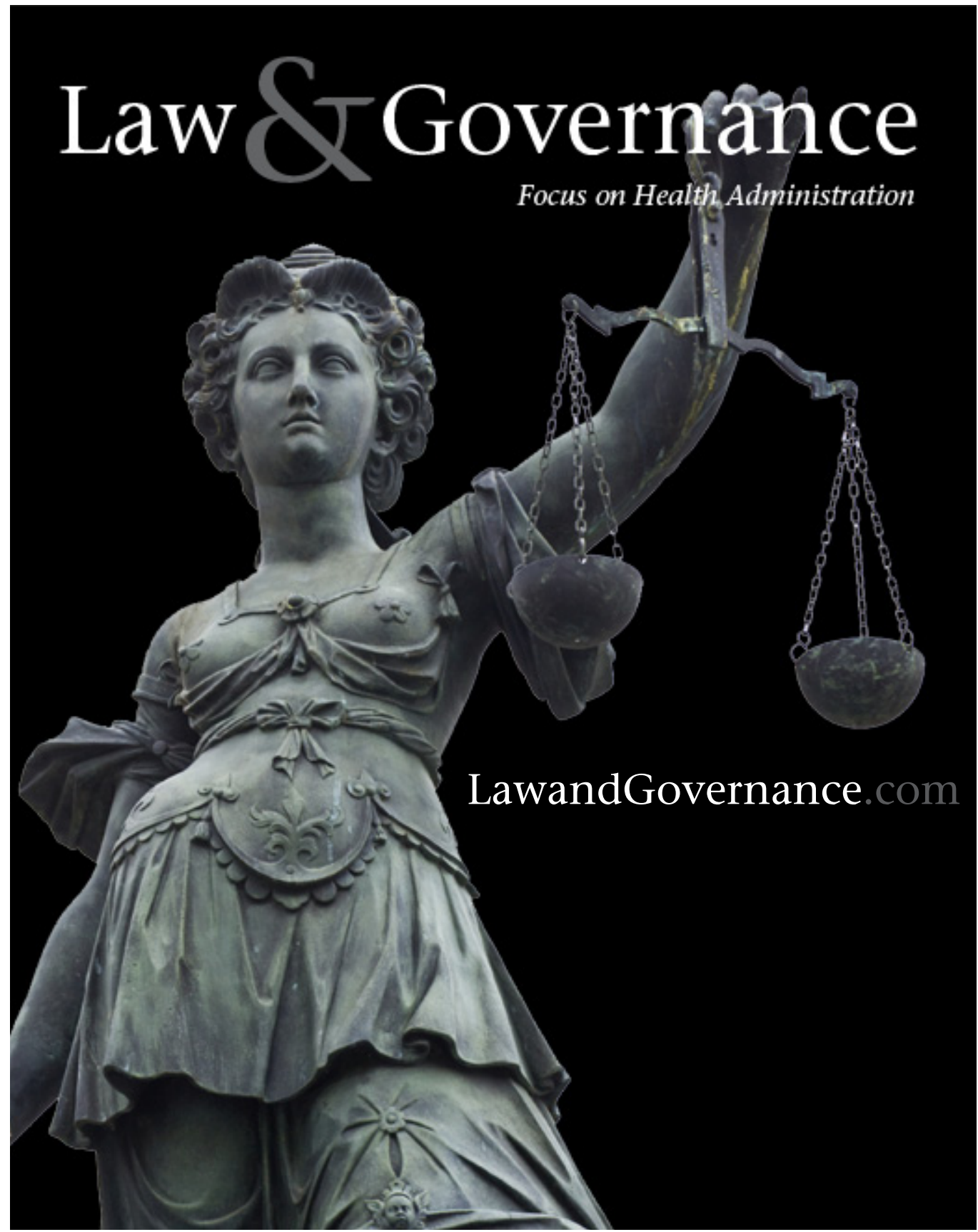

